\title{
The Illocution Functions In Twilight Movie Dialogues: From Politeness Study Point of View
}

\author{
Devi Mulatsih \\ Program Studi Pendidikan Bahasa Inggris, Universitas Swadaya Gunung Jati Cirebon, Indonesia \\ *dmulatsih83@gmail.com
}

DOI: $10.20884 / 1 . j 1 \mathrm{i} .2021 .12 .1 .2773$

\begin{abstract}
Article History:
First Received:

ABSTRACT

$12 / 06 / 2020$

This research aims to analyze politeness based on the types of illocution

Final Revision: functions that belong to Leech's theory. This study is descriptive qualitative

$15 / 06 / 2021$ research and the data were collected through the literature review study. Data

Available online: source taken from Twilight movie dialogues, to analyze the illocutions

$30 / 06 / 2021$ function used in daily life. The results of the analysis displayed in percentage form based on Bungin formula. This research used 208 data from the utterances of movie dialogues that represented the types. The analysis focused on two illocution functions, such as competitive and convivial for the 208 utterances which represent all the data. The result showed that Competitive $(50,96 \%)$ and Convivial $(49,04 \%)$ are the most dominant utterances which appear between the characters in Twilight movie dialogues.
\end{abstract}

Keywords: pragmatic; speech act; illocution acts; politeness; Leech politeness theory

\section{INTRODUCTION}

Language is a very important thing in our daily life. It is used for communication with other people around the globe in society. People use a language for everything they do. Even, they do not say anything, they had through in their mind using a language. People can interact with each other by using language to convey meaning with different purposes and get someone to do something by either commanding directly or using a more polite way (indirectly). In all major studies of politeness (Lakoff, 1973; Leech, 1983; Brown and Levinson, 2008; Ervin-Tripp, 1976; Blum-Kulka, 1987; Ide, 1989; Fraser, 1990; Kasper, 1990), there appears to be general agreement that there are different degrees of politeness manifested in linguistic expressions. This 
certainly lends theoretical support to the intuitive view that polite expressions can be put on a graduated scale ranging from very polite to impolite.

Pragmatics studies of meaning affected by context. It means pragmatics state language context relates to the context of the situation. The same utterances may have different meanings in a different context. Yule (1996) states that pragmatics is concerned with the study of meaning as communicated by a speaker/writer interpreted by a listener/reader. Moreover, Yule (1996) assumes that "Pragmatic is appealing because it's about how people make sense of each other linguistically, but it can be a frustrating area of study because it requires us to make sense of people and what they have in mind". A conversation will be successful if the speaker's utterance cooperates with the listener's intentions. It means that how the speaker leads communication more than said, the speaker's utterance can be predicted by the listener. So, in doing this research the writer choose politeness based on the illocution functions type in movie dialogues and the type of illocution function most occur in the selected scene in the movie. The Twilight movie is a fiction romantic drama movie based on the novel written by Stephanie Meyer. It was directed by Catherine Hardwicke and released on 21 November 2008. This film is about the relationship between Isabella Swan and Edward Cullen who is a vampire and the purpose of The Cullens to protect Bella from the harm vampires. The reason why the writer has chosen the movie because the writer expects that the dialogues in the movie contain exist in real life, even though the writer knows that the movie dialogue is fictional.

Based on the explanation above, the writer is interested to analyze the topic. So, this research was aimed at knowing the types of illocution functions that occur in Twilight movie dialogues, and to know the dominant utterances which appear on the character in Twilight movie dialogues. In this research, the writer discussed the types of illocution functions concerning politeness used by the speaker in the movie. The transcription of the dialogues in the Twilight movie is used as the data. These data were analyzed by using a pragmatic theory of Yule (1996) and Akmajian (1979), the speech act theory of Yule (1996), and the theory of Leech (1983).

Pragmatics as of linguistics branch studies meaning besides semantics and semiotics. This subject is relatively new if we compared it to others. As Yule (1996) said that "Pragmatics is concerned with the study of meaning as communicated by a speaker (or writer) interpreted by a listener (or reader)". It means that pragmatics meaning may connect the speaker's utterance and listener interpretation (assumption).

Pragmatics meaning cannot interpret semantically because Pragmatics depends on the context. The two primary forms of context important to pragmatics are linguistic context and 
situational context. Linguistics context means the utterance meaning determined linguistically and situational context is related to the situation where the conversation is done.

Akmajian (1979) put on some minimal requirements on adequate pragmatics theory in discussing pragmatics. According to him, a pragmatic theory:

a. must contain a classification of a speech act;

b. must contain analysis and definitions of the various speech acts;

c. must contain a specification of various uses of expressions: it must say that:

1. Expression $e$ is standardly (literally and directly) used to do $X$ (in context $C$ ).

2. Expression $e$ has different $n$ users.

3. Expression $e$ and $e ́$ have the same use and use.

d. must relate literal and direct language use to such phenomena as:

1. Linguistic structure (semantics, syntax, phonology)

2. The structure of the communication situation, the course of conversations, and social institutions (pragmatic) presuppositions, and understanding.

3. Speaker-meaning, implication, presupposition, and understanding.

According to Akmajian (1979), some philosophers have been mainly concerned with categorizing the type of speech acts and defining each category. They have pursuing goals (a) and (b). Linguists have been concerned mainly in the specification, such as ambiguity and synonym. The five disciplines which are interest in persuading these goals are philosophy, psychology, sociology, and anthropology.

Yule (1996) states that "actions performed via utterances are generally called speech acts". He assumes that speech acts commonly given more labels, such as apology, complaint, compliment, invitation, promise, or request. A speech act has an illocutionary point or illocutionary force. The action performed by producing an utterance will consist of three related acts. They are:

1. Locutionary Acts.

Locutionary act is the basic act of utterances or producing meaningful linguistic expression.

2. Illocutionary Acts

Illocutionary act is performed via the communicative force of an utterance. The illocutionary point of speech act must be distinguished from its perlocutionary effect, which is what it brings about.

3. Perlocutionary Acts 
Its perlocutionary effect may be the doing of the thing by the person-directed. Sentences in different grammatical moods, the declarative, imperative, and interrogative, tend to perform speech acts of specific sorts.

But in particular contexts, one may perform a different speech act using them than that for which they are typically put to use. Thus, as noted above, one may use a sentence such as "it's cold in here" not only to make an assertion but also to request that one's auditor turn up the heat. Speech acts include performative utterances, in which one performs the speech act by using a firstperson present tense sentence that says that one is performing the speech act. Examples are: "I promise to be there", "I warn you to turn yourself in", etc. some specialized devices for performing speech acts are exclamations and physics, such as "Ouch!" and "Hello!", respectively. The former is used to perform an expensive speech act and the latter for greeting someone.

In doing conversation or make it a conversation, both speaker and also listener need politeness. According to Leech (1983), politeness more than civilized but politeness is one of the missing link between cooperative principle and the problems how to connecting force and sense. Politeness in an interaction can be defined as the mean employed awareness of another person's face. According to Leech (1983) politeness can be divided into six maxims, there are:

\section{Tact Maxim}

Minimize cost to others; maximize the benefit to others.

2. Generosity Maxim

Minimize benefit to self; maximize cost to self.

3. Approbation Maxim

Minimize dispraise; maximize praise of others.

4. Modesty Maxim

Minimize prise of self; maximize dispraise of self.

5. Agreement Maxim

Minimize disagreement between self and other; maximize agreement between self and other.

6. Sympathy Maxim

Minimize antipathy between self and other; maximize antipathy between self and other.

In this case, the writer chose only tact maxim because it is the most important of politeness principle.

The differences in situations are claiming the types and the degree of politeness. Generally, illocution functions have classified into four functions. There are: 
a. Competitive

The purpose of illocution competitive is competed with social purposes, i.e. commanding, requesting, claiming, cadging, and advising. A competitive function has the purpose of reducing competition between the addressee's purpose and what the politeness claimed.

b. Convivial

The purpose of illocution convivial is parallel with social purpose, i.e. offering, inviting, addressing, thanking, congratulating, promising, apologizing, greeting, forgiving, praising. A convivial function has a purpose to find out affable.

c. Collaborative

The purpose of illocution is paying no regard to social purpose, i.e. stating, reporting, announcing, teaching, and advising. Collaborative functions were not relevant to politeness and almost speech including to this category.

d. Conflictive

The purpose of illocution conflictive is conflicts with social purpose, i.e. menacing, alleging, cursing, angering. It means that conflict is the opposite of politeness. Conflict makes someone angry.

The analysis of this research emphasizes to find out politeness which is presented by tact maxim viewed from illocution functions.

\section{MATERIALS AND METHOD}

\section{Research Method}

In this research, the writer used a mixed-method that combined quantitative and qualitative approaches. According to Creswell (2014) state, the mixed method is the research approach that is combined or associates qualitative form and quantitative form. This research is social phenomenon research. Putra \& Hendarman (2013) said that if you want to make research social phenomena accurately, completely, and deeply, it should use a mixed method. Qualitative and quantitative approaches have advantages and disadvantages. According to Creswell (2014) state that qualitative research is the method for exploring and understanding the meaning that some individuals or groups of people perceive comes from a social or human problem. Meanwhile, according to Creswell (2014) quantitative research is a "method for testing certain theories by examining the relationship between variables."

\section{Data Collecting Technique}


The data are collected by applying documentary methods. Qualitative research involves purposeful use for describing, explaining, and interpreting data collecting. The data of the research are collected in the following steps:

a. The writer watches the movie many times to have a deep understanding of the story along with its context.

b. Searching the movie's script while identifying the dialog which belongs to the illocution function type.

c. Classifying the utterances into more specific types, i.e. Competitive, Convivial, Collaborative, and Conflictive, and all the data analyzed based on Leech's theory.

d. Selecting the relevant data.

e. Simplifying the selected data to support the analysis.

f. Reporting the collecting data.

\section{Data Analysis Technique}

The data that the writer collected from Twilight movie dialogue then analyzed them by using the theory of illocution functions. Then the writer accounts for the data by using Bungin's formula (2005) to get the percentage illocution functions type that appears in the data. The following formula is:

$$
\begin{aligned}
& \mathbf{n}=\mathbf{F x} / \mathbf{N} \cdot 100 \% \\
& \text { n : percentage of illocution functions type } \\
& \text { Fx : individual frequency of type } \\
& \mathrm{N} \text { : total number of all type }
\end{aligned}
$$

The systematic procedures in conducting the analysis are as follows:

1. Reading the script of the selected scene repeatedly.

2. Identifying the dialog which belongs to the illocution function type.

3. Classifying the utterances into more specific types, i.e. competitive, convivial, collaborative, and conflictive, and all the data analyzed based on Leech's theory.

4. Calculating the data in percentage, the illocution function type occurs mostly in the script.

5. Describing some conclusions based on the result of the analysis.

\section{Data Source}


The writer took the data in the research from the Twilight movie. The writer has only chosen the utterances of the characters in the movie from the script. The script was taken from the internet which was written by Melissa Rosenberg.

\section{RESULTS \& DISCUSSION}

\section{Findings}

The findings data of the research are Convivial and Competitive illocution functions. Here, the writer wants to describe the type of illocution functions below:

\section{Convivial}

Convivial is an act that the illocutionary goal coincides with the social goal. Convivial is more positive politeness and aims to find opportunities for social time. The functions of convivial are offering, inviting, welcoming, greeting, thanking, praising, asking, introducing, apologizing, promising, requesting, and congratulating. This type shows the harmony between speaker and receiver to emphasize a sense of solidarity which implied mutual respect or carrying out the principle of politeness.

Table 1. Greeting

\begin{tabular}{lll}
\hline No. & Utterances & \multicolumn{1}{c}{ Analysis } \\
\hline 1 & "Bye, Bella!" & $\begin{array}{l}\text { The utterance means to give the greeting } \\
\text { to Bella as the hearer. }\end{array}$ \\
2 & $\begin{array}{l}\text { "Glad you're finally here. Charlie hasn't } \\
\text { shut up about it since you told him you } \\
\text { were coming." }\end{array}$ & $\begin{array}{l}\text { The happy because the speaker finally back } \\
\text { is harks } \\
\text { to Forks. }\end{array}$ \\
\hline
\end{tabular}

Table 2. Congratulating

\begin{tabular}{lll}
\hline No. & Utterances & Analysis \\
\hline 1 & "Good luck at your school! They ADLIB & The utterance means to give the wishing \\
& $\begin{array}{l}\text { superficial good wishes "Don't forget to } \\
\text { write "We'll miss you." }\end{array}$ & \\
\hline
\end{tabular}

Table 3. Praising

No. Utterances Analysis




\begin{tabular}{lll}
\hline 1 & "Very romantic." & The hearer praises the speaker that the \\
& idea is very romantic \\
& The hearer praises the homecoming gift \\
& from her father.
\end{tabular}

Table 4. Asking

\begin{tabular}{lll}
\hline No. & Utterances & Analysis \\
\hline 1 & "How's your mom?" & $\begin{array}{l}\text { The hearer asking about the condition of } \\
\text { the speaker's mother }\end{array}$ \\
2 & "I'm going to the prom with Eric! I just & $\begin{array}{l}\text { The hearer asks the speaker to make sure } \\
\text { that she wants to go out the town or not. }\end{array}$ \\
\hline
\end{tabular}

Table 5. Welcoming

\begin{tabular}{|c|c|c|}
\hline No. & Utterances & Analysis \\
\hline 1 & $\begin{array}{l}\text { "I'm Jacob. We made mud pies together } \\
\text { when we were little kids." }\end{array}$ & $\begin{array}{l}\text { The hearer introducing himself to the } \\
\text { speaker and remind her of their childhood. }\end{array}$ \\
\hline 2 & $\begin{array}{l}\text { "Welcome, Ms. Swan. Follow along as } \\
\text { best you can till you get caught up." }\end{array}$ & The hearer tries to welcome the speaker. \\
\hline
\end{tabular}

Table 6. Offering

\begin{tabular}{lll}
\hline No. & Utterances & Analysis \\
\hline 1 & "You've missed a lot of the semester, but & The hearer offers the hook to the speaker \\
$\begin{array}{l}\text { I can hook you up - tutor, cliff notes, } \\
\text { medical excuse." }\end{array}$ & $\begin{array}{l}\text { The hearer offers the speaker to use the } \\
\text { microscope at first. }\end{array}$ \\
\hline
\end{tabular}

Table 7. Introducing

\begin{tabular}{lll}
\hline No. & Utterances & Analysis \\
\hline 1 & "I'm Mike. Newton." & $\begin{array}{l}\text { The hearer greeting the speaker by } \\
\text { mention his name. }\end{array}$ \\
\hline
\end{tabular}

Table 8. Apologizing

\begin{tabular}{lll}
\hline No. & Utterances & Analysis \\
\hline 1 & "Are you alright? I warned them not to & $\begin{array}{l}\text { The hearer apologizes to the speaker } \\
\text { because she cannot play volleyball } \\
\text { actually and in the context, the ball was hit } \\
\text { his head. } \\
\text { The hearer apologizes to the speaker } \\
\text { because she wants to take a picture. }\end{array}$ \\
\hline
\end{tabular}

Table 9. Thanking 


\begin{tabular}{lll}
\hline No. & Utterances & Analysis \\
\hline 1 & "That'd be great, thank you." & The hearer said thank you to the speaker. \\
2 & "And thank you. For the tires." & The hearer said thank you to the speaker. \\
\hline
\end{tabular}

Table 10. Inviting

\begin{tabular}{lll}
\hline No. & Utterances & Analysis \\
\hline 1 & "I'm glad you're not dead 'cause - well, & The hearer invites the speaker to go with \\
that would suck, plus I wanted to ask you him to prom. & hem \\
- even though it's, like, a month away ... \\
So what do you think? Do you want to go? \\
To prom. With me." \\
“... and yeah, prom committee is a chick The hearer invites the speaker to prom. \\
thing, but I gotta cover it for the paper \\
anyway, and they need a guy to help \\
choose the music - - So, I need your \\
playlist-“
\end{tabular}

Table 11. Promising

\begin{tabular}{lll} 
No. Utterances & Analysis \\
\hline 1 & "I'm fine, dad. Calm down." & $\begin{array}{l}\text { The hearer promises the speaker that she } \\
\text { is fine. } \\
\text { The hearer convinces the speaker that it is } \\
\text { okay. }\end{array}$ \\
\hline
\end{tabular}

Table 12. Requesting

\begin{tabular}{llll}
\hline No. & Utterances & \multicolumn{1}{c}{ Analysis } \\
\hline 1 & $\begin{array}{l}\text { "There's whale watching, too. Come } \\
\text { with." }\end{array}$ & $\begin{array}{l}\text { The hearer requests the speaker to come } \\
\text { with them to La Push Beach. }\end{array}$ \\
\hline
\end{tabular}

\section{Competitive}

Competition is an act that the illocutionary goal competed with the social goal. In this type, politeness had a negative nature and aims to reduce disharmony. The functions of competitive are: ordering, demanding, asking, begging, requesting, insisting, alleging, and prohibiting.

Table 13. Insisting

\begin{tabular}{lll} 
No. & Utterances & Analysis \\
\hline 1 & "We waited, but we were starving -" & $\begin{array}{l}\text { The hearer insists to the speaker because } \\
\text { they were starving when they waiting for } \\
\text { her. }\end{array}$ \\
\hline
\end{tabular}

Table 14. Asking 


\begin{tabular}{lll}
\hline No. & Utterances & Analysis \\
\hline 1 & Bella, you remember Billy Black." & $\begin{array}{l}\text { The hearer asking the speaker to } \\
\text { remember someone. } \\
\text { The hearer asking the speaker to explain } \\
\text { what that means. }\end{array}$ \\
\hline
\end{tabular}

Table 15. Requesting

\begin{tabular}{lll}
\hline No. Utterances & \multicolumn{1}{c}{ Analysis } \\
\hline 1 & $\begin{array}{l}\text { "So what do you think of your } \\
\text { homecoming gift?" }\end{array}$ & $\begin{array}{l}\text { The hearer asking the speaker's opinion } \\
\text { about the homecoming gift (a truck) }\end{array}$ \\
2 & $\begin{array}{l}\text { "Would you mind just pointing me toward } \\
\text { Mr. Varner's class?" }\end{array}$ & $\begin{array}{l}\text { The hearer requests to point her toward } \\
\text { Mr. Vamer's class. }\end{array}$ \\
\hline
\end{tabular}

Table 16. Praising

\begin{tabular}{lll}
\hline No. & Utterances & Analysis \\
\hline 1 & "No way. The truck is for me?" & $\begin{array}{l}\text { The hearer was surprised and praised the } \\
\text { truck. } \\
\text { The hearer was praised to rebuilt the } \\
\text { engine to the speaker. }\end{array}$ \\
\hline
\end{tabular}

Table 17. Demanding

\begin{tabular}{lll}
\hline No. & Utterances & Analysis \\
\hline 1 & $\begin{array}{l}\text { "Okay, so you gotta double pump the } \\
\text { clutch when you shift, but -“ }\end{array}$ & $\begin{array}{l}\text { The hearer demands the speaker when she } \\
\text { shifts, she gotta double pump the clutch. } \\
\text { "Block it, Chloe! Yeah! Good attack!" } \\
\text { The hearer demands the speaker to block } \\
\text { the ball. }\end{array}$ \\
\hline
\end{tabular}

Table 18. Begging

\begin{tabular}{lll}
\hline No. & Utterances & Analysis \\
\hline 1 & "He's totally gorgeous, obviously. But & The hearer tries to beg the speaker to not \\
apparently, no one here is good enough for & waste her time to like him because no one \\
him. Like I care. Anyway, don't waste & good enough for him there. \\
your time." & "I just don't like narrow-mindedness." & $\begin{array}{l}\text { The hearer begs the speaker that he does } \\
\text { not like narrow-mindedness. }\end{array}$ \\
\hline
\end{tabular}


Table 19. Ordering

\begin{tabular}{lll} 
No. $\quad$ Utterances & Analysis \\
\hline 1 & "I think I can keep up." & $\begin{array}{l}\text { The hearer orders the speaker that he can } \\
\text { keep up the secret of her. }\end{array}$ \\
2 & "I keep thinking Eric's going to ask me to & $\begin{array}{l}\text { The hearer orders the speaker to ask Eric } \\
\text { to go to prom with her. }\end{array}$ \\
\hline
\end{tabular}

Table 20. Prohibiting

\begin{tabular}{lll}
\hline No. & Utterances & Analysis \\
\hline 1 & "Now, you know if you change your mind, & The hearer prohibits if the speaker \\
I'll race back here from wherever the changes her mind, she will take her back. \\
game is."
\end{tabular}

Table 21. Alleging

\begin{tabular}{lll}
\hline No. & Utterances & Analysis \\
\hline 1 & "You said before ... That you heard what & The hearer alleges the speaker to read \\
those guys were thinking ... Can you... & minds because he could read minds. \\
read minds?"
\end{tabular}

\section{Discussions}

After analyzing each of the utterances, it is found that there are utterances that can be included to illocution function viewed from politeness especially in tact maxims in Twilight movie dialogues. So, the writer just finds out competitive and convivial functions in the Twilight movie dialogues because both of them relate to politeness principle especially tact maxim. Below the percentage of each of the functions:

1. Competitive : 106 data or $50,96 \%$

2. Convivial : 102 data or $49,04 \%$

Table 22. Competitive and Convivial

\begin{tabular}{lll}
\hline No. & Competitive & Convivial \\
\hline 1 & Ordering, & Offering, \\
\hline 2 & Demanding, & Inviting, \\
\hline 3 & Asking, & Welcoming, \\
\hline 4 & Begging, & Greeting, \\
\hline 5 & Requesting, & Thanking, \\
\hline 6 & Insisting, & Praising, \\
\hline 7 & Alleging, & Asking, \\
\hline 8 & Prohibiting & Introducing, \\
\hline
\end{tabular}




\begin{tabular}{ll}
\hline 9 & Aplogizing, \\
\hline 10 & Promising, \\
\hline 11 & Requesting, \\
\hline 12 & Congratulating \\
\hline
\end{tabular}

From the 208 data of utterance in movie dialogues, the most dominant utterances were used by the character in the movie are competitive and convivial illocution functions because the competitive is related to compete with a social purpose. It is to reduce competition between the addressee's purpose and what the politeness claimed. While the convivial functions are related to social purposes. It is important to pay attention to language politeness. Politeness would bring good relations in social life next. It can be seen in people's life which is reflected in the movie. The character in the movie is still preserving good social relations by using politeness.

\section{CONCLUSION}

After analyzing the utterances in Twilight movie dialogues written by Melissa Rosenberg based on the novel Twilight which was written by Stephanie Meyer, it can be seen that each of the illocution functions consists of 106 utterances of competitive functions or 50,96\% and convivial functions consist of 102 utterances or 49,04\%. All of the utterances are 208 utterances. So, the most dominant illocution functions that are using in the Twilight movie are competitive and convivial illocution functions because it is to reduce competition between the hearer's purpose and what the politeness claimed. While convivial is used for social functions. The forms of competitive illocution act are: Ordering, Demanding, Asking, Begging, Requesting, Insisting, Alleging, and Prohibiting. The forms of convivial illocution act are Offering, Inviting, Welcoming, Greeting, Thanking, Praising, Asking, Introducing, Apologizing, Promising, Requesting, and Congratulating.

\section{REFERENCES}

Akmajian, A., Farmer, A. K., Bickmore, L., Demers, R. A., Harnish, R. M. (1979). Linguistics: An Introduction to Language and Communication. Massachussets: MIT Press.

Al-Bantany, N. F. (2013). The Use of Commissive Speech Acts and Its Politeness Implication: A Case of Banten Gubernatorial Candidate Debate. Journal Passage, Vol. 1(2): 21-34.

Ardi, H., Nababan., Djatmika., Santosa, R. (2016). Politeness Strategy in Indonesian Translation: Has it Already Changed?. Prosiding Prasasti. Retrieved From: https://jurnal.uns.ac.id/prosidingprasasti/article/view/1536. DOI: https://doi.org/10.20961/pras.v0i0.1536.

Austin, J.L. (1962). How to Do Things with Words. London: Oxford University Press. 
Brown, P. and Stephen, C. L. (2008). Politeness Some Universals in Language Use. Great Britain: Cambridge University Press.

Creswell, J. W. (2014). Research Design: Qualitative, Quantitative, and Mixed Methods Approaches. United Kingdom: Sage Publications, Inc.

Ervin, S., Tripp. (1976). Language and Society. Cambridge: Cambridge University Press.

Ide, S. (1989). Formal Forms and Discernment: Two Neglected Aspects of Universals of Linguistic Politeness. Multilingual-Journal of Cross-Cultural and Interlanguage Communication, (8): 223-248.

Junaidi, M. (2017). Politeness, Speech Act, and Discourse In Sasak Community. Mabasan Journal, Vol. 11 (1): 1-17. DOI: https://doi.org/10.26499/mab.v11i1.48.

Kasper, G. (1990). Linguistic Politeness: Current Research Issues. Journal of Pragmatics, (14): 193-218. DOI: http://dx.doi.org/10.1016/0378-2166(90)90080-W.

Kravchenko, N. (2017). Illocution of direct speech acts via conventional implicature and semantic presupposition // Lege artis. Language yesterday, today, tomorrow. The Journal of University of SS Cyril and Methodius in Trnava. Warsaw: De Gruyter Open, 2017, vol. II(1), June 2017. p. 128168. DOI: 10.1515/lart-2017-0004.

Lakoff, R. (1973). Language and Women's Place. Cambridge: Cambridge University Press.

Leech, G. (2011). Prinsip-Prinsip Pragmatik. Jakarta: Universitas Indonesia Press.

Levinson, S. (1983). Pragmatics. Cambridge: Cambridge University Press.

Nastiti Putri, M., Sukartha, I., \& Evi Wahyu Citrawati, N. (2017). Tindak Ilokusi dan Strategi Bertutur Tokoh dalam Novel Supernova: Akar Karya Dewi Lestari. Humanis, 20(1), 66-74. Retrieved from https://ojs.unud.ac.id/index.php/sastra/article/view/32922.

Peccei, J.S. (1999). Pragmatics. Guangzhou: Taylor \& Francis Ltd.

Saeed, J.I. (1997). Semantics. China: Blackwell Publisher Ltd.

Tri Budiasih, L. (2018). Illocution on Speech Acts of Foreign Students in Indonesian Learning. PAROLE: Journal of Linguistics and Education, 6(2), 41-48. https://doi.org/10.14710/parole.v6i2.41-48

Yayuk, R. (2017). Kesantunan Konvivial Pada Masyarakat Banjar di Kelurahan Sekumpul, Martapura. Jurnal Mabasan, Vol. 11(3): 128-147. DOI: https://doi.org/10.26499/mab.v11i2.3.

Yule, G. (1996). Pragmatics. Oxford: Oxford University Press. 